\title{
Madrigal apasionado
}

Quisiera estar en tus labios

Para apagarme en la nieve

De tus dientes.

Quisicra estar en tu pecho

Para en sangre deshacerme.

Quisiera en tu cabellera

De oro soñar para siempre.

Que tu corazón se hiciera

Tumba del mío doliente.

Que tu carne sea mi carne,

Quemi frente sea tu frente.

Quisiera que toda mi alma

Entrara en tu cuerpo breve

Y ser yo tu pensamiento

Y ser yo tu blanco veste.

Para hacer que te enamores

De mí con pasión tan fuerte

Que te consumas buscándome

Sin que jamás ya me encuentres.

Para que vayas gritando

Mi nombre hacia los ponientes,

Preguntando por iní al agua,

Bebiendo triste las hieles

Que antes dejó en el camino

Mi corazón al quererte

$Y$ yo mientras iré dentro

De tu cuerpo dulce y débil,

Siendo yo, mujer, tú misma

$Y$ cstando en ti para siempre.

Mientras tú en vano me buscas

Desde Oriente a Occidente.

Hasta que al fin nos quemara

La llama gris de la muerte. 